\title{
Microbial population structures in activated sludge before and after the application of synthetic polymer
}

\author{
${ }^{*}$ D. F. Juang, L. J. Chiou \\ Department of Healthcare Administration, Mei-Ho Institute of Technology, Ping Tung 912, Taiwan \\ Received 13 November 2006; revised 30 November 2006; accepted 1 December 2006; available online 1 January 2007
}

\begin{abstract}
Since Juang (2005) has found that the sludge settleability became much worse and the flocs displayed as pin flocs in only a few days after the addition of synthetic polymer was halted, it is hypothesized that the shift of microbial population in activated sludge before and after the addition of synthetic polymer might have occurred. Therefore, the identification of microbial population in the activated sludge of a lab-scaled continuous-flow type of treatment reactor was conducted at different phases of this study. The results of this study showed that the presence of synthetic polymer inhibited the growth of dominant bacteria and floc-formers in activated sludge, but gave a competitive advantage of growth to some other bacteria. The addition of synthetic polymer has caused the shift of microbial population and affected the growth of floc-formers in activated sludge. It took more than one month for the population structure of predominant microorganisms in activated sludge to return more closely to the initial population structure.
\end{abstract}

Key words: Activated sludge, floc-formers, microbial population, synthetic polymer

\section{INTRODUCTION}

Seka, et al. (2001) and Juang (2005) has concluded that synthetic polymer could be used to solve the filamentous bulking problem in activated sludge systems. However, it was also found that the sludge settleability became much worse and the flocs displayed as pin flocs in only a few days after the addition of synthetic polymer was discontinued (Juang, 2005). And, it took more than one month for the system to return to normal operation. Since the flocs appeared tiny and fragile after the addition of synthetic polymer was halted, it was hypothesized that the addition of synthetic polymer might have seriously damaged the floc-formers or dominant bacteria and rendered a shift in the microbial population structure of the activated sludge. Many kinds of bacteria isolated from the activated sludge of different wastewater treatment systems were reported, and many of them might play very important roles on the formation of strong flocs (Snaidr, et al., 1997, Spellman, 1997, Seviour and Blackall, 1999, Nielsen, et al., 1999, Juang and Morgan, 2001, Liu, et al., 2005). Although Richard (1989) also mentioned that synthetic polymer could overcome the physical effects of filaments on sludge settling, there *Corresponding author, Email: x2060@email.meiho.edu.tw Tel: 88687799821 ext.8331; Fax: 88687780657 are no other detailed reports available specifying how synthetic polymer affects the microbial population structure in activated sludge. Tabata, et al. (1999) has concluded that certain strains of bacteria can hydrolyze high molecular weight synthetic polymers, however it is unknown that the synthetic polymer used to improve sludge settling characteristics in this study will not affect the growth of microorganisms in activated sludge. Therefore, this research was then conducted to investigate the microbial population structures in activated sludge before and after the addition of synthetic polymer. This Research have been done in Mei-Ho Institute of Technology on February 2002 until December 2003.

\section{MATERIALS AND METHODS}

The whole research period was divided into three phases as shown in Fig. 1 (Juang, 2005). During Phase I, no polymer was used, and the system was allowed to operate until steady-state operation was achieved. In Phase II, a synthetic polymer was added and the system was continuously operated until steady-state operation was achieved, and polymer addition was then halted. During Phase III the activated sludge system was again operated without polymer addition. However, 


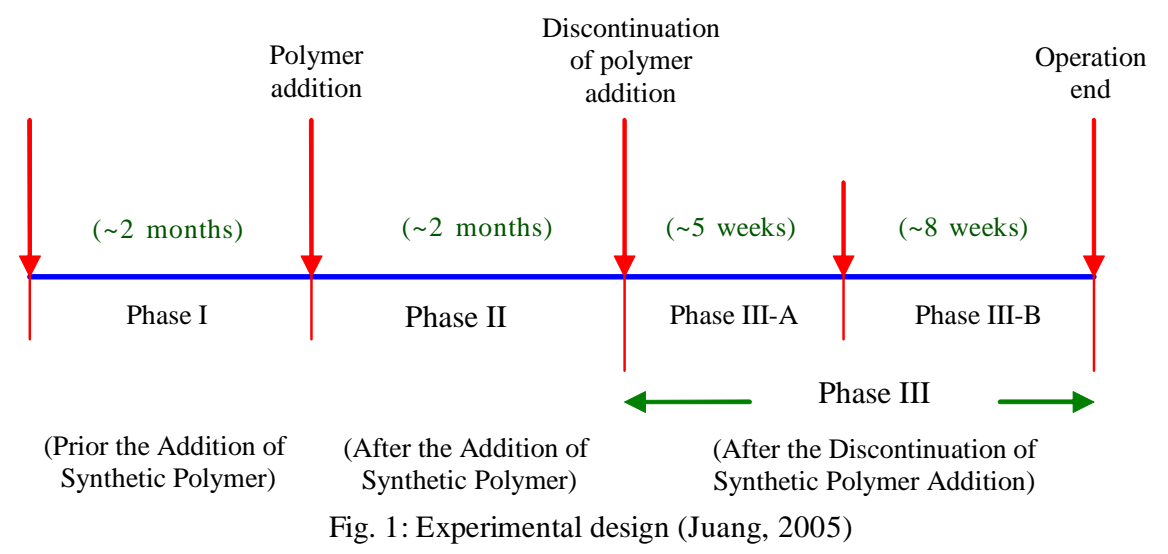

this phase was divided into two more phases, called Phase III-A and Phase III-B, to obtain more detailed information about the effects of synthetic polymer on the microbial population structure. The detailed descriptions of the lab-scaled continuous-flow type of treatment reactor (CFSTR), the operating data, the feed composition, the methods for confirmation of steady state and the methods for isolation and identification of microbes were all presented by Juang and Morgan (2001) and Juang (2005) previously. In this study, conventional tests were used for the identification of bacteria. The water samples taken from the effluent of clarifier and the sludge samples taken directly from the aeration tank were analyzed at the end of each phase following the methods mentioned in Standard Methods (Clesceri, et al., 2001). One type of synthetic polymer, which has been popularly used at wastewater treatment plants, was selected in this study. The manufacturer released no detail information on the constituents of the polymer except that formaldehyde was present, the molecular weight was between 2,500,000 and 3,500,000, the absolute viscosity was between $1,600,000$ and $1,900,000 \mathrm{cps}$, and the bulk density was about 112.3 $\mathrm{lb} / \mathrm{ft}^{3}$. The synthetic polymer was applied based upon a typical used ratio of $1 \mathrm{~mL}$ the concentrate per $10 \mathrm{~L}$ activated sludge.

\section{RESULTS}

Microbial population structure during phase I

The effluent quality and the sludge characteristics of the system during this phase are shown in Table 1 (Phase I). According to the data in this table, it is obvious that the system operated well during the first month after start-up. The sludge settled readily and the clear effluent was obtained. However, after one

month the filamentous bulking occurred. The TSS and the turbidity in the effluent rose to an average value of $7.83 \mathrm{mg} / \mathrm{L}$ and to a range of $4.0 \mathrm{NTU}$ to $8.0 \mathrm{NTU}$, respectively. The SVI increased rapidly in a few days and then held steady in the range between $350 \mathrm{~mL} / \mathrm{g}$ and $360 \mathrm{~mL} / \mathrm{g}$ for the rest time of this phase. Basically, the activated sludge flocs during this phase could be described as healthy and large. At the end of this phase, sludge samples were taken for the analysis of microbial population structure. Some higher protists and worms, were found during this phase. Flagellated protozoa such as Peranema sp., Anisonema sp., and Bodo sp. were observed. Cilated protozoa such as Chilodonella uncinata, Aspidisca cicada (or costata), Tetrahymena pyriformis, Vorticella convallaria, and Carchesium polypinum were found in great number. Some other tiny and actively freeswimming protozoa were also observed in abundance. One amoeba, Amoeba proteus, and one rotifer, Philodina sp., were seen in the activated sludge of this system. In addition, there were many pigmented roundworms, possibly Monhystera, found in the system. Many pigmented algae were also seen attached to the sludge flocs. The large number and diversity of species of higher protists and roundworm observed indicated a healthy system. The initial bacterial population structure was presented in Table 2 (Phase I). It was obvious that Brevibacterium acetylicum and Pseudomonas vesicularis were two of the most dominant species isolated on both nutrient agar and feed agar. The bacterial count of $B$. acetylicum on nutrient agar $\left(34 \times 10^{6} \mathrm{cfu} / \mathrm{mL}\right)$ was about the same as that on feed agar $\left(36 \times 10^{6} \mathrm{cfu} / \mathrm{mL}\right)$. However, the count of $P$. vesicularis on nutrient agar was much more than that on feed agar. Similar results were observed for other less dominant bacteria. 
Int. J. Environ. Sci. Tech., 4 (1): 119-125, 2007

Table 1: Effluent quality and sludge characteristics during each phase

\begin{tabular}{|c|c|c|c|c|c|c|c|c|c|}
\hline \multicolumn{2}{|l|}{ Phases } & \multicolumn{2}{|c|}{ Phase I } & \multicolumn{2}{|l|}{ Phase II } & \multicolumn{3}{|c|}{ Phase III-A } & \multirow[b]{2}{*}{\begin{tabular}{l}
\multicolumn{1}{c}{ Phase III-B } \\
$12^{\text {th. Week }}$ \\
after \\
polymer \\
addition \\
was halted
\end{tabular}} \\
\hline Items anc & erating status & $\begin{array}{l}\text { Before } \\
\text { filamentous } \\
\text { bulking }\end{array}$ & $\begin{array}{l}\text { After } \\
\text { filamentous } \\
\text { bulking }\end{array}$ & $\begin{array}{l}\text { Polymer } \\
\text { addition }\end{array}$ & $\begin{array}{l}1^{\text {st. }} \text { Week } \\
\text { After } \\
\text { polymer } \\
\text { addition } \\
\text { was halted }\end{array}$ & $\begin{array}{l}2^{\text {nd. Week }} \\
\text { after } \\
\text { polymer } \\
\text { addition } \\
\text { was halted }\end{array}$ & $\begin{array}{l}3^{\text {rd. Week }} \\
\text { after } \\
\text { polymer } \\
\text { addition } \\
\text { was halted }\end{array}$ & $\begin{array}{l}5^{\text {th. Week }} \\
\text { after } \\
\text { polymer } \\
\text { addition } \\
\text { was halted }\end{array}$ & \\
\hline \multirow{2}{*}{ Effluent } & TSS (mg/L) & $\sim 2$ & $\sim 7.83$ & $\sim 2$ & 17.5 & 254 & 20 & 2 & $\sim 8$ \\
\hline & Turbidity (NTU) & $\sim 1.1$ & $4 \sim 8$ & $\sim 1$ & $\sim 11$ & 50 & 14 & $4.5 \sim 14.7$ & $4 \sim 11$ \\
\hline $\begin{array}{l}\text { Sludge } \\
\text { charact }\end{array}$ & SVI (mL/g) & $150 \sim 165$ & $350 \sim 360$ & $99 \sim 131$ & 310 & 410 & 158 & 133 & $300 \sim 385$ \\
\hline
\end{tabular}

For example, Aeromonas hydrophila, Acinetobacter calcoaceticus, Pasteurella aerogenes, Achromobacter group V D, and one Arthrobacter sp. were only found in nutrient agar, while $P$. maltiphila, Comamonas testosteroni, and Acaligenes faecalis were only isolated from feed agar. The counts for these bacteria were generally quite low (most ranged $1-6 \times 10^{6} \mathrm{cfu} / \mathrm{mL}$ ), thus the fact that they were not isolated on both media may not be significant. Some other bacteria such as Arthrobacter spp. II and III, Corynebacterium sp. I, Ps. putrefaciens, Ps. pickettii, A. caviae, V. fluvialis, and $F$. indologenes were all isolated from both agars, although they were not very dominant in the activated sludge system. Therefore, considering the whole population structure of the activated sludge, there was no apparent or significant difference between the results obtained from nutrient agar and that from feed agar.

\section{Microbial population structure during Phase II}

After the system began to receive the synthetic polymer, the settling characteristics of the activated sludge improved greatly and the filamentous bulking problem was solved. The total suspended solids in the effluent dropped to about $2.0 \mathrm{mg} / \mathrm{L}$, and the turbidity decreased to an average value of about 1.0 NTU (see Table 1). The SVI values varied between $99 \mathrm{~mL} / \mathrm{g}$ and $131 \mathrm{~mL} / \mathrm{g}$. The addition of synthetic polymer during this phase apparently enhanced the sludge flocculation and caused the formation of larger and heavier flocs.

After only two days of synthetic polymer addition, the population structure of higher protists underwent an obvious change. Flagellated protozoa such as Peranema sp., Anisonema sp. and Bodo sp. were no longer observed. The same was true of the ciliated protozoa, Chilodonella uncinata, Amoeba proteus and one rotifer, Philodina sp.. The pigmented roundworm (possibly Monhystera) also disappeared gradually. A few Aspidisca cicada (or costata), the ciliated protozoa, were seen in the first few days after the addition of synthetic polymer, but disappeared later. Unidentified tiny free-swimming protozoa were still present, but the population was less than before. Several species of ciliated protozoa such as Tetrahymena pyriformis, Vorticella convallaria, and Carchesium polypinum were present and one new ciliated protozoan, Paramecium sp. was observed in great quantity. Evidently, the population structure of higher protists was affected by the addition of synthetic polymer. Both their number and diversity declined. Similar results were obtained during the entire polymer addition period. The algal population however did not appear to change much. Numerous pigmented algae were still found attaching on the activated sludge flocs. Overall, many higher protists, especially free-swimming protozoa and rotifers, were adversely affected by the addition of synthetic polymer.

The population structure of predominant bacteria shifted considerably. The dominant bacteria isolated at the end of this phase are also listed in Table 2 (Phase II). Brevibacterium acetylicum, a Gram-positive bacteria, was still one of the most predominant species found in both nutrient agar or feed agar, however its population was somewhat reduced from $34 \times 10^{6} \mathrm{cfu} /$ $\mathrm{mL}$ to $20 \times 10^{6} \mathrm{cfu} / \mathrm{mL}$ in nutrient agar and from $36 \times 10^{6}$ $\mathrm{cfu} / \mathrm{mL}$ to $23 \times 10^{6} \mathrm{cfu} / \mathrm{mL}$ in feed agar. Pseudomonas vesicularis, which had been one of the most predominant bacteria, was also present in much lower numbers in nutrient agar (only $7 \times 10^{6} \mathrm{cfu} / \mathrm{mL}$ ) and in feed agar (only 4 x $10^{6} \mathrm{cfu} / \mathrm{mL}$ ). Therefore, the numbers of both predominant species were significantly reduced with the addition of synthetic polymer. However, the number of Aeromonas hydrophila obviously increased from $2 \times 10^{6} \mathrm{cfu} / \mathrm{mL}$ to $12 \times 10^{6} \mathrm{cfu} / \mathrm{mL}$ in nutrient agar. This bacteria was not isolated from feed agar previously, but was found at $14 \times 10^{6} \mathrm{cfu} / \mathrm{mL}$ during this phase of 
Microbial population structures in activated sludge...

Table 2. Predominant bacteria isolated from CFSTR at the end of each phase

\begin{tabular}{|c|c|c|c|c|c|c|c|}
\hline \multirow{2}{*}{$\begin{array}{l}\text { Phase I } \\
\text { Nutrient agar medium }\end{array}$} & \multicolumn{2}{|c|}{ Phase II } & \multicolumn{2}{|c|}{ Phase III-A } & \multicolumn{2}{|c|}{ Phase III-B } & \multirow[b]{2}{*}{$\begin{array}{l}\text { Counting } \\
(\mathrm{cfu} / \mathrm{mL})\end{array}$} \\
\hline & $\begin{array}{l}\text { Counting } \\
\text { (cfu/mL) }\end{array}$ & Nutrient agar medium & $\begin{array}{l}\text { Counting } \\
(\mathrm{cfu} / \mathrm{mL})\end{array}$ & Nutrient agar medium & $\begin{array}{l}\text { counting } \\
\text { (cfu/mL) }\end{array}$ & Nutrient agar medium & \\
\hline $\begin{array}{l}\text { Brevibacterium } \\
\text { acetylicum }\end{array}$ & $34 \times 10^{6}$ & $\begin{array}{l}\text { Brevibacterium } \\
\text { acetylicum }\end{array}$ & $20 \times 10^{6}$ & $\begin{array}{l}\text { Brevibacterium } \\
\text { acetylicum }\end{array}$ & $7 \times 10^{6}$ & $\begin{array}{l}\text { Brevibacterium } \\
\text { acetylicum }\end{array}$ & $5 \times 10^{6}$ \\
\hline Arthrobacter sp. I * & $8 \times 10^{6}$ & Arthrobacter sp. IV * 2 & $2 \times 10^{6}$ & $\begin{array}{l}\text { Pseudomonas } \\
\text { vesicularis }\end{array}$ & $33 \times 10^{6}$ & Micrococcus roseus & $2 \times 10^{6}$ \\
\hline Arthrobacter sp. II * & $3 \times 10^{6}$ & Corynebacteriumsp. I* 2 & $2 \times 10^{6}$ & $\begin{array}{l}\text { Achromobacter } \\
\text { group VD\#\# }\end{array}$ & $2 \times 10^{6}$ & $\begin{array}{l}\text { Pseudomonas } \\
\text { vesicularis }\end{array}$ & $101 \times 10^{6}$ \\
\hline Arthrobacter sp. III * & $2 \times 10^{6}$ & $\begin{array}{l}\text { Pseudomonas } \\
\text { vesicularis }\end{array}$ & $7 \times 10^{6}$ & Aeromonas hydrophila & $12 \times 10^{6}$ & $\begin{array}{l}\text { Comamonas } \\
\text { testosteroni }\end{array}$ & $2 \times 10^{6}$ \\
\hline Corynebacterium sp. I * & $1 \times 10^{6}$ & Aeromonas caviae $^{* *} 6$ & $6 \times 10^{6}$ & Aeromonas sorbia & $3 \times 10^{6}$ & Alcaligenes faecalis & $4 \times 10^{6}$ \\
\hline Pseudomonas vesicularis & $35 \times 10^{6}$ & Aeromonas hydrophila 1 & $12 \times 10^{6}$ & $\begin{array}{l}\text { Acinetobacter } \\
\text { calcoaceticus var lwoffi }\end{array}$ & $7 \times 10^{6}$ & $\begin{array}{l}\text { Achromobacter } \\
\text { group VD\#\# }\end{array}$ & $1 \times 10^{6}$ \\
\hline $\begin{array}{l}\text { Pseudomonas } \\
\text { putrefaciens }\end{array}$ & $1 \times 10^{6}$ & Vibrio fluvialis & $3 \times 10^{6}$ & $\begin{array}{l}\text { Flavobacterium } \\
\text { indologenes }\end{array}$ & $2 \times 10^{6}$ & $\begin{array}{l}\text { Aeromonas } \\
\text { hydrophila }\end{array}$ & $5 \times 10^{6}$ \\
\hline $\begin{array}{l}\text { Pseudomonas } \\
\text { pickettii biovar } 2\end{array}$ & $3 \times 10^{6}$ & $\begin{array}{l}\text { Flavobacterium } \\
\text { indologenes }\end{array}$ & $2 \times 10^{6}$ & Pasteurella aerogenes & $8 \times 10^{6}$ & Aeromonas sorbia & $4 \times 10^{6}$ \\
\hline Aeromonas caviae** & $2 \times 10^{6}$ & Pasteurella aerogenes 6 & $6 \times 10^{6}$ & Aeromonas caviae $^{* *}$ & $2 \times 10^{6}$ & Vibrio fluvialis & $3 \times 10^{6}$ \\
\hline $\begin{array}{l}\text { Achromobater } \\
\text { group VD\#\# }\end{array}$ & $6 \times 10^{6}$ & Unidentified \# & $50 \times 10^{6}$ & Klebsiella oxytoca & $1 \times 10^{6}$ & $\begin{array}{l}\text { Flavobacterium } \\
\text { meningosepticum }\end{array}$ & $1 \times 10^{6}$ \\
\hline Vibrio fluvialis & $2 \times 10^{6}$ & & & Unidentified \# & $55 \times 10^{6}$ & $\begin{array}{l}\text { Pseudomonas } \\
\text { paucimobilis }\end{array}$ & $1 \times 10^{6}$ \\
\hline $\begin{array}{l}\text { Flavobacterium } \\
\text { indologenes }\end{array}$ & $4 \times 10^{6}$ & & & & & & \\
\hline $\begin{array}{l}\text { Acinetobacter } \\
\text { calcoaceticus var lwoffi }\end{array}$ & $7 \times 10^{6}$ & & & & & & \\
\hline Pasteurella aerogenes & $5 \times 10^{6}$ & & & & & & \\
\hline Feed agar medium & $\begin{array}{l}\text { Counting } \\
\text { (cfu/mL) }\end{array}$ & Feed agar medium & $\begin{array}{l}\text { Counting } \\
\text { (cfu/mL) }\end{array}$ & Feed agar medium & $\begin{array}{l}\text { Counting } \\
\text { (cfu/mL) }\end{array}$ & Feed agar medium & $\begin{array}{l}\text { Counting } \\
\text { (cfu/mL) }\end{array}$ \\
\hline $\begin{array}{l}\text { Brevibacterium } \\
\text { acetylicum }\end{array}$ & $36 \times 10^{6}$ & $\begin{array}{l}\text { Brevibacterium } \\
\text { acetylicum }\end{array}$ & $23 \times 10^{6}$ & $\begin{array}{l}\text { Brevibacterium } \\
\text { acetylicum }\end{array}$ & $8 \times 10^{6}$ & $\begin{array}{l}\text { Brevibacterium } \\
\text { acetylicum }\end{array}$ & $9 \times 10^{6}$ \\
\hline Arthrobacter sp. II * & $1 \times 10^{6}$ & Arthrobacter sp. V* & $1 \times 10^{6}$ & $\begin{array}{l}\text { Pseudomonas } \\
\text { vesicularis }\end{array}$ & $44 \times 10^{6}$ & Arthrobacter sp.VI* & $4 \times 10^{6}$ \\
\hline Arthrobacter sp. III * & $5 \times 10^{6}$ & Corynebacteriumsp. I* & $* 1 \times 10^{6}$ & $\begin{array}{l}\text { Acinetobacter } \\
\text { calcoaceticus var lwoffi }\end{array}$ & $11 \times 10^{6}$ & Micrococcus roseus & $1 \times 10^{6}$ \\
\hline Corynebacterium sp. I * & $5 \times 10^{6}$ & $\begin{array}{l}\text { Pseudomonas } \\
\text { vesicularis }\end{array}$ & $4 \times 10^{6}$ & $\begin{array}{l}\text { Comamonas } \\
\text { testosteroni }\end{array}$ & $3 \times 10^{6}$ & $\begin{array}{l}\text { Pseudomonas } \\
\text { vesicularis }\end{array}$ & $100 \times 10^{6}$ \\
\hline Pseudomonas vesicularis & $12 \times 10^{6}$ & $\begin{array}{l}\text { Pseudomonas } \\
\text { putrefaciens }\end{array}$ & $1 \times 10^{6}$ & $\begin{array}{l}\text { Pseudomonas } \\
\text { maltiphila }\end{array}$ & $1 \times 10^{6}$ & $\begin{array}{l}\text { Achromobacter } \\
\text { group VD\#\# }\end{array}$ & $1 \times 10^{6}$ \\
\hline $\begin{array}{l}\text { Pseudomonas } \\
\text { putrefaciens }\end{array}$ & $2 \times 10^{6}$ & $\begin{array}{l}\text { Pseudomonas pickettii } \\
\text { biovar } 2\end{array}$ & ii $3 \times 10^{6}$ & Pseudomonas diminuta & $1 \times 10^{6}$ & $\begin{array}{l}\text { Comamonas } \\
\text { acidovoran }\end{array}$ & $1 \times 10^{6}$ \\
\hline Pseudomonas maltiphila & $4 \times 10^{6}$ & Aeromonas caviae $* *$ & $1 \times 10^{6}$ & Pasteurella aerogenes & $3 \times 10^{6}$ & Alcaligenes faecalis & $9 \times 10^{6}$ \\
\hline $\begin{array}{l}\text { Pseudomonas pickettii } \\
\text { biovar } 2\end{array}$ & $3 \times 10^{6}$ & Alcaligenes faecalis & $2 \times 10^{6}$ & & & Aeromonas sorbia & $6 \times 10^{6}$ \\
\hline Aeromonas caviae** & $1 \times 10^{6}$ & Aeromonas hydrophila & $14 \times 10^{6}$ & & & & \\
\hline Comamonas testosteroni & $2 \times 10^{6}$ & & & & & & \\
\hline Alcaligenes faecalis & $1 \times 10^{6}$ & & & & & & \\
\hline Vibrio fluvialis & $1 \times 10^{6}$ & & & & & & \\
\hline $\begin{array}{l}\text { Flavobacterium } \\
\text { indologenes }\end{array}$ & $4 \times 10^{6}$ & & & & & & \\
\hline
\end{tabular}

Note: * "I”, "II", "III", "IV", "V" and "VI" were labeled to represent different species.

** Most closely resembling this species.

\# Could not be found in any references (API Diagnostic Lab).

\#\# New name: Ochrobactrum anthropi 
the study. A new "Unidentified” bacterium (Its identity could not be determined.) was found to be the most predominant species in nutrient agar $\left(50 \times 10^{6} \mathrm{cfu} / \mathrm{mL}\right)$, although it was not isolated from feed agar. The results of some other less dominant microorganisms shown in Table 2 also displayed the population shift after the addition of synthetic polymer.

Therefore, it is believed that the whole population structure of the predominant bacteria was significantly changed by the addition of the synthetic polymer. The new isolates and the species, which exhibited prominence in population, apparently had obtained a competitive advantage in the presence of synthetic polymer.

\section{Microbial population structure during Phase III-A}

During the first week of Phase III-A (after the addition synthetic polymer was halted), the sludge settleability became worse. The turbidity of the effluent increased to a value within the range of $10 \mathrm{NTU}$ to $12 \mathrm{NTU}$, the total suspended solids in the effluent rose to $17.5 \mathrm{mg} /$ $\mathrm{L}$, and the SVI value increased gradually from $193 \mathrm{~mL} /$ $\mathrm{g}$ to $310 \mathrm{~mL} / \mathrm{g}$. In about one more week, the turbidity of the effluent rose to $50 \mathrm{NTU}$, the total suspended solids in the effluent increased up to $254 \mathrm{mg} / \mathrm{L}$, and the SVI rose from $310 \mathrm{~mL} / \mathrm{g}$ to $410 \mathrm{~mL} / \mathrm{g}$. However, the sludge settleability started to improve during the third week of this phase. The TSS in the effluents dropped to about $20 \mathrm{mg} / \mathrm{L}$, the turbidity of the effluent ranged between 8 NTU and 16 NTU, and the SVI dropped rapidly down to $158 \mathrm{~mL} / \mathrm{g}$. Finally, the system was operating well and the sludge settleability was normal again during the fourth and fifth weeks. Most higher protists and worms, which disappeared while polymer was being added, were observed again in about two weeks after the polymer addition was halted. For example, two ciliated protozoa, Aspidisca cicada (or costata) and Chilodonella uncinata were found again in only a few days. One rotifer, Philodina sp. as well as the pigmented roundworm (possibly Monhystera) also reappeared in the aeration basin. The unidentified tiny free-swimming protozoa looked more active than before. Ciliated protozoa such as Tetrahymena pyriformis, Vorticella convallaria, and Carchesium polypinum were also observed in a great number just like before. Plenty of the ciliated protozoan, Paramecium sp. which was first observed while polymer was being added, were still seen. However, flagellated protozoa such as Peranema sp., Anisonema sp. and Bodo sp. were no longer observed. Amoeba proteus was also never seen in the activated sludge during this phase. From the results presented above, it is obvious that the population structure of higher protists and worms somewhat returned to the normal (initial) pattern, although a few of them were still never found again. The population structure of bacteria during this phase is also listed in Table 2(Phase III-A). The number of Brevibacterium acetylicum obviously decreased again (only $7 \times 10^{6} \mathrm{cfu} / \mathrm{mL}$ in nutrient agar and $8 \times 10^{6} \mathrm{cfu} / \mathrm{mL}$ in feed agar). Conversely, the population of Ps. vesicularis increased to $33 \times 10^{6} \mathrm{cfu} /$ $\mathrm{mL}$ in nutrient agar and $44 \times 10^{6} \mathrm{cfu} / \mathrm{mL}$ in feed agar. Also, it is interesting that except for Brevibacterium acetylicum no other Gram-positive bacteria were isolated. Again, the "Unidentified" organism (the same one) was still the most predominant species found in nutrient agar $\left(55 \times 10^{6} \mathrm{cfu} / \mathrm{mL}\right)$. Aeromonas hydrophila was still seen in a great quantity $\left(12 \times 10^{6} \mathrm{cfu} / \mathrm{mL}\right)$ in nutrient agar, but none was isolated from feed agar this time. By camparing the results of Phase I, II, and III-A shown in Table 2, it can be seen that another new microbial population shift has been happening during Phase III-A.

\section{Microbial population structure during Phase III-B}

During this phase, the turbidity was in the range of 4.0 NTU to $11.0 \mathrm{NTU}$, the average total suspended solid in the effluent was about $8.0 \mathrm{mg} / \mathrm{L}$, and the SVI was always between $300 \mathrm{~mL} / \mathrm{g}$ to $385 \mathrm{~mL} / \mathrm{g}$. The population structure of higher protists was very similar to that noted at Phase III-A. However, many more of pigmented roundworms were observed, and Aspidisca cicada (or costata), one of the ciliated protozoa, was only occasionally seen. The predominant bacteria during this phase are also listed in Table 2. Obviously another population shift had occurred during the three months interval of Phase III. Although few new microorganisms, which were presented only in smaller numbers, were identified, Ps. vesicularis was still the most predominant species. The "Unidentified" species, which had been most dominant previously, was not isolated again. In nutrient agar the population of Aeromonas hydrophila was less than before and it was also not isolated from feed agar. B. acetylicum was still present in the activated sludge and its population was very close to that noted previously. Basically, the population did not return to its original (before polymer addition). 


\section{DISCUSSION AND CONCLUSION}

Floc formers have been long believed to be the most predominant bacteria in activated sludge. According to the microbial population structure described in Phase II, it is obvious that the growth of some predominant bacteria or floc-formers was inhibited by synthetic polymer. Looking at the results associated with the microbial population shifts observed for this activated sludge system, it seems that Ps. vesicularis was a critical organism. Thus, Ps. vesicularis could be a major floc-former in this activated sludge system. In fact, this species has been reported to be a floc-former (Horan and Eccles, 1986). Although the population of $A$. calcoaceticus varied in a manner similar to that of $P$ s. vesicularis, it has not been reported to be a floc-former. The population of $B$. acetylicum decreased while polymer was added and never returned to the initial level. It is postulated that this bacterium was inhibited by the synthetic polymer and could not compete with other predominant species again after polymer addition was halted. The "Unidentified" bacterium was the most predominant species while polymer was being added. It is presumed that in the presence of synthetic polymer it had a competitive advantage that caused its population to increase dramatically. However, this bacterium did not lose its predominance immediately after polymer was removed from the system. Similarly, Aeromonas hydrophila also showed an increase in its population with the addition of synthetic polymer and still retained its domination after the polymer was halted. Therefore, it may be concluded that the addition of synthetic polymer has obviously rendered a shift in the population structure of the activated sludge. It seems that the presence of synthetic polymer will inhibit the growth of dominant bacteria and floc former, such as Ps. vesicularis, in the activated sludge, but give a competitive advantage of growth to some other bacteria, such as the "Unidentified" one and $A$. hydrophila. Similar results on the shift of population structure for higher protists in activated sludge before and after the addition of synthetic polymer were also observed in this study. Since the growth of some predominant bacteria or floc-formers could be inhibited by synthetic polymer, the sludge settleability became much worse and the flocs displayed as "pin flocs" in only a few days after the addition of synthetic polymer was halted (Juang, 2005). According to the results of Phase III-A and Phase III-B in this study, it took more than one month for the system to be operated normally and for the population structure of predominant microorganisms in activated sludge to return more closely to the initial population structure. This may be the reason why the sludge settleability became much worse during the first few weeks after the discontinuation of synthetic polymer.

\section{REFERENCES}

Clesceri L.S., Greenberg A.E., Eaton, A.D., (2001). Standard methods for the examination of water and wastewater, American Public Health Association (APHA), American Water Works Association (AWWA) and Water Environment Federation (WEF), USA.

Horan, N.J., Eccles, C.R., (1986). Purification and characterization of extracellular polysaccharide from activated sludge, Water Res., 20 (11), 1427-1432.

Juang, D.F., Morgan, J.M., (2001). The applicability of the API 20E and API Rapid NFT systems for the identification of bacteria from activated sludge, Elec. J. Biotechn., 4 (1), $1-7$.

Juang, D.F., (2005). Effects of synthetic polymer on the filamentous bacteria in activated sludge, Biores. Technol., 96, 31-40.

Liu, Y., Zhang, T. and Fang, H.H.P., (2005). Microbial community analysis and performance of a phosphateremoving activated sludge, Biores. Technol., 96, 1205-1214.

Nielsen, A.T., Liu, W.T., Philips, C., Grady, L. Jr., Molin, S., Stahl, D.A., (1999). Identification of a novel group of bacteria in sludge from a deteriorated biological phosphorus removal process, Appl. Environ. Microbiol., 65, 1251-1258.

Richard, M.G., (1989). Activated sludge microbiology, Water Environment Federation (WEF), Alexandria, Virginia, USA.

Seka, A.M., Van de Wiele, T., Verstraete W., (2001). Feasibility of a multi-component additive for efficient control of activated sludge filamentous bulking, Water Res., 35 (12), 2995-3003.

Seviour, R.J., Blackall, L.L., (1999). The microbiology of activated sludge, Kluwer Academic Publishers, USA.

Snaidr, J., Amann, R., Huber, I., Ludwig, W. and Schleifer, K.H., (1997). Phylogenetic analysis and situ identification of bacteria in activated sludge. Appl. Environ. Micro., 63 (7), 2884-2896

Spellman, F.R., (1997). Microbiology for water/wastewater operators, Technomic Publishing Co. Inc., Lancaster, PA, USA.

Tabata, K., Kasuya, K.I., Abe, H., Masuda, K., Doi, Y., (1999). Poly (aspartic acid) degradation by a Sphingomonas sp. Isolated from freshwater, Appl. Environ. Micro., 65 (9), 4268-4270. 


\section{AUTHOR (S) BIOSKETCHES}

Juang, D. F., Ph.D., is associate professor in the Department of Healthcare Administration, Mei-Ho Institute of Technology, Taiwan. Email: x2060@email.meiho.edu.tw

Chiou, L. J. , M.S., is lecturer in the Department of Healthcare Administration, Mei-Ho Institute of Technology, Taiwan. Email: x3175@mail.meiho.edu.tw

This article should be referenced as follows:

Juang, D. F., Chiou, L. J. , (2007). Microbial population structures in activated sludge before and after the application of synthetic polymer. Int. J. Environ. Sci. Tech., 4 (1), 119-125. 